\title{
LOOKING FOR THE CAUSES OF A CONVERGENCE: THE CONTRIBUTION OF SOCIAL ANALYSIS ON THE STUDY OF CONTEMPORARY CONSTITUTIONAL
}

LAW

\author{
BUSCANDO AS CAUSAS DA CONVERGÊNCIA: A CONTRIBUIÇÃO DA ANÁLISE \\ SOCIAL NO ESTUDO DO DIREITO CONSTITUCIONAL CONTEMPORÂNEO
}

\author{
Jacopo Paffarini* \\ Leandro Caletti**
}

\begin{abstract}
Recent comparative law studies have remarked the role of "metalegal" formants for a complete description of legal language. It is necessary to recognize the dialectic character of a social product - as law - which explain the matters related with a legal command effectiveness. Is the subject of legal studies the construction of a method of social analysis? Or any study must take into consideration any particular social experience without possibility to build a general method? In the first case we affirm that in similar social context the normative rules assume a certain degree of similarity. In the second, we deny any logic of the legal experience: thus, every legal system is "singular". In order to exit from this contrast, we should look at what is moving inside the social organization and realizing the law "as social practice".
\end{abstract}

Keywords: Convergence of Constitutional Ideas; Metalegal Formants; Law as a social practice.

Resumo: Recentes estudos da área de comparação jurídica têm destacado o papel do formato "metalegal" na completa descrição da linguagem normativa. É preciso reconhecer a matriz dialética de um produto social - como o direito - para explicar as problemáticas inerentes à efetividade do comando legal. Seria correto afirmar que o objeto dos estudos jurídicos é a criação de uma metodologia de análise social? Ou, ao contrário, se deveria considerar cada experiência jurídica sem a possibilidade de construir uma metodologia geral? Na primeira hipótese, se afirma que, em contextos similares, as normas apresentam um certo grau de similaridade. Na segunda, é denegada qualquer logica à experiência jurídica: cada sistema é "singular". Ao efeito de resolver a contradição, se deve olhar para o que se move no interior da organização social, pensando o direito "como pratica social".

Palavras-Chave: Convergência de ideais constitucionais; Formato Metalegal; O Direito como pratica social.

\footnotetext{
* Doutor em Direito Público (Università degli Studi di Perugia/Itália). Pós-Doutor em Direito Público (Faculdade Meridional IMED). E-mail: jacopo.paffarini@imed.edu.br

** Mestre em Direito pela Faculdade Meridional (Bolsista PROSUP/CAPES). Professor do Curso de Direito das Faculdades João Paulo II. Professor do Programa de Pós-Graduação "Lato Sensu" em Direito da Faculdade Meridional (IMED). Membro dos Grupos de Pesquisas "Transnacionalismo e Circulação de Modelos Jurídicos" e "Ética, Cidadania e Sustentabilidade", vinculados ao Programa de Pós-Graduação "Stricto Sensu" em Direito da Faculdade Meridional (IMED). Assessor Jurídico da União (Advocacia-Geral da União). Advogado (OAB/RS). E-mail: calettileandro@gmail.com
} 


\section{INTRODUCTION}

As one of the main outcomes of comparative method is shaping models of knowledge related to a particular branch of law, the matter of their "effectiveness" has gradually gained a central position within jurist's debate. A «juridical model» is the «arrangement»used to represent one or more legal experiences, thus, a combination of abstractions - respecting a prearranged logic - to which their description has been devolved.

The organization of the complexity of a legal phenomenon is a necessary premise to communicate the information acquired by the observation of normative facts. The jurist's perception plays an important role in that systematization: the way he/she focuses on particular features explains the criteria used for the conceptualization of the normative language and the classification that follows.

There is a preliminary point that we might take into account: any classification of legal models needs foreign law studies. The jurist which "stay" just in one legal system faces all the time same systematic data and cannot perceive/distinguish them from the context they are part of ${ }^{1}$. Therefore, one of the main debate on comparative law doctrine concerns the opportunity to build an inductive method in order to allow the jurists to go beyond the normative formant and to get in touch with the background of legal relationships.

Actually, as it has been observed, «an inference-oriented scholarship is still difficult to come by» ${ }^{2}-$ specially in the field of constitutional law, where is used to call «comparative» single-country studies and it seems to prevail a «universalist approach» which brings jurists to overtook the historical basis of the transnational dialogue on constitutional models $^{3}$.

Apart from classification (and in combination with it), comparative law have developed a new horizon of research, which scope is highlighting the episodes of circulation of legal models, their causes and cases of "cross-fertilization" with local law. That process claim for a new reflection on the case-study selection, that is, making it more functional to the aim of underpinning or deny a particular hypothesis or concept.

This objective has been often persecuted through a simple quantitative pattern, which cannot always satisfy a scientific standard, nor guarantees the effectiveness of the concept created. In particular, the only way to accept a quantitative data research is overtake the peculiarity and causes of a national experience and looking just at the common features. 
Otherwise, how a proper "western model" of - for example - right to speech could be obtained from comparison if we (seriously) take into consideration all the "western" national provisions on defamation, hate-speeches, privacy protection, right to information?

Quite often, an "assonance" among normative provisions of the different national systems represents a "false-start" for comparative studies, especially in absence of an advanced case-law or when one or both the regulation have not been enforced yet. In that case, the research is at stake and the only way to come out is looking beyond legal formants.

Therefore, as it has been noticed, «a good theory requires to clarify concepts as well as offering causal explanation for observed phenomena» ${ }^{4}$. The same need emerges from another point of view: if we assume that a "pure" and "neutral" description of social phenomena (including legal) is not an achievable goal, it should be considered a good practice adding "explanations" to the simple "portrayals". Thus, the analysis of origins and causes could also reveal different matrix of similar legal institute. For example, the historical experience of dictatorship gives reason of the compulsory voting in Brazil, while the low-rate of social conflict and political stability explain why U.S. citizens have to request the Public Administration for being included in the electoral lists. Consequently, taking the rights in their contest allows jurist to learn more about their function, while, on the contrary, "universalist tones" are often challenged by the "law practice".

The most important challenge for a comparative law scholar is building "enduring" juridical models, shaping them «through multiple description» 5 of singular national institutes and normative framework. Specifically, we could say that a juridical model is «enduring» when it is able to include in a descriptive framework the essential characteristics and functions of a specific institute, as they emerge from each national experience and notwithstanding the endemic dialectic of each legal systems.

The "gap" created by the enforcement of provisions is a traditional matter of the most dedicated comparative doctrine, for which "law" is «both the propositional statement as such and its invested meaning - which jointly constitute the rule» ${ }^{6}$. However, can we perceive the «invested meaning» as the simple interpretation given by the judge/P.A. or there is something more beyond "wording" and "will"? At the aim to avoid a strict alternative, this contribution highlights how a better understanding of the contemporary circulation of some legal model is possible if we pay attention to the recent evolution of productive process and 
social assets.

In compliance with an «inference oriented approach» this paper offers some practical cases/tendencies to check if is possible to define new legal transplants fostered by globalization process and, eventually, which of them are the most frequent. Furthermore, we will notice that the object of transplant in most of the cases are "ideas", and not proper "models", as the still ongoing "dialogue" between national and international institution expresses an intellectual convergence whose empirical outcome are still uncertain.

\section{BEYOND THE "LAW IN THE BOOKS" AND THE "LAW IN ACTION".}

From a juridical perspective, the ordinary consequences of social dialectic is the modification of legal relationships, as the balances go in favor of one or more classes rather than others. Sometimes this brings to change the normative texts - and so it affects the legislative language - while more frequently the innovation is reached trough interpretation process and law enforcement in general - a path that has been defined «judicialization of democracy» ${ }^{7}$.

In this perspective, comparative studies in the field of constitutional law have progressively adopted an interdisciplinary approach, as the juridical categories have never been the products of the sole normative language (the "law in the books") or the will of the enforcement bodies (the "law in action"). The basis of constitutional law are deeply rooted in the society "as a whole", such as the last one find in the law is main cause of transformation/perpetuation (continuity/discontinuity).

However, even if the first relationship is the most studied by jurists, the second is perceived as an "extra", a further study outside the jurists' task (and scientific field). The first consists in discover the historical, economic and political causes of a constitutional institute, so it assume a shift from society to legal discourse. The second outlines how the law change society, thus, the normative language is observed in the perspective of its practical impacts, unusual for legal studies.

Since long time legal positivism considers the last approach as "useless" at the aim of legal theory, while its outcome should have some function in justice theory's building. Although there have been a never-stopped dialogue between scholars, the ordinariness is a strict separation of legal discourse and sociological, economic discourses. The chronological 
coincidence between legal positivism and the emergence of the State, first, and democratic pluralism, than, can explain the need for an autonomous foundation of the legal concepts and why this autonomy sometimes turns in a "presumption of neutrality".

By fostering the objective nature of legal solution - as it derived from democratic institutions - political powers and the courts use to legitimize the conservation of one or a set of norms or a legal system. During the XX century only few times the jurists have seriously considered to push the research beyond the procedure - the formal aspect of democracy trying to reveal the social factors hidden behind the normative fact $^{8}$.

In the 90s more than 110 countries have reformed or entirely rewritten its constitution. It cannot be a coincidence that - despite the multiplicity of causes that have given rise to the constituent processes - there is a similarity of the constitutional models adopted. The ethical and ideological legacy of the twentieth century is thus carved in the preambles, in the preliminary articles and, in general, in all those formulations from which one can infer the State political principles.

The 90s mark also the end of the ideological conflict that had divided the world, as the lives of many people, but during which - anyway - were achieved the highest level of participation of the masses in the political life of the national and international community. The mechanisms shaped by the state social democracy guaranteed the development of the constitutional models that drove the State economic government notwithstanding the dialectic between different social interests.

A part of those models - in particular the economic freedoms and personal liberties - inspired the "transformation" - what has been called a «constitutionalization» - of international law and defines the objectives of the main supranational organizations controlled by the geopolitical bloc of liberal nations. On the contrary, the social rights remain anchored to the local sphere, compelled by the crisis of state sovereignty and unlikely to be compatible with the development model defined by the powerful dynamics of global finance.

\section{LAW AS SOCIAL PRACTICE: WHAT IS A DIALECTIC APPROACH FOR CONSTITUTIONAL STUDIES}

However, if the market globalization has reflexively forged a juridical one, it 
cannot be affirmed a direct-casual nexus between law and economics. The point is not if law shapes economic dynamics or, on the contrary, the economic problems are currently monopolizing the legal concepts.

The aim is to consider the law - at the same time - a «product» and an «instrument for social-life production», which operate according to its own logic and procedures and by mean of its institutions". In this perspective, the "judicial renovation" of constitutionalism, even if it can be perceived as a refuse of legal positivism, preserves its strict legalist characters.

The research of a new legitimacy for the exercise of public power beyond State sovereignty produced a break of the democratic foundation of constitutionalism, which, until now, have not been fixed with other than judicial techniques (growing use of proportionality test, driven comparative interpretation, ect.). Consequently, so far as the normative discourse remains closed on itself, the legal concept are used as the "glasses" through which looking at reality.

This attitude supposes an acceptance of reality "as it is": it brings to the transformation of the "social assets and facts" into "binding social assets and facts", as the mandatory nature of law disappears because its existence is "natural"10.

As an example, consider the «constitutional traditions common to the Member States» of European Union (art. 6 of the EU Treaty), as they were detected by the "comparative reasoning" of the Luxemburg Court of Justice. Are they now an "effective" characteristic of EU law while the integration process has spread to 28 countries? Are we sure that they ever were during the first steps? Or should we rather say that a common constitutional heritage in Europe is being built - just as in the past - through the interpretations and "functional comparisons" of the Court of Justice and the political conditionality imposed by the so called "Copenhagen criteria"? ${ }^{11}$.

The crisis of global finance has played an important role in determining the current complexity of transnational relationship between the public authorities and people, on the one hand, and between the same private entities, on the other. If the first steps of the "legal globalization" were characterized by a considerable attention to the "local" legal tradition, now we are assisting to a process of centralization of economic policies by the supranational institutions and the Western States.

Thus, "judicial dialogue", "multilevel protection of fundamental rights" and "legal 
Are Brazilian Courts Democratic Institutions? A Hermeneutic Analysis of Legitimacy

pluralism" have apparently lost their leading position among the causes of migration of constitutional ideas.

\section{HOW METALEGAL FORMANTS AND SOCIAL ANALYSIS CAN CONTRIBUTE. UNDERSTANDING THE NEW ROLE OF JUDICIARY}

The contribution offered by the social inquiry can enlighten, not only the impact of law on society, but also its "reflexive effects", i.e. the role played by the social structure in shaping legal categories.

In this perspective, the recent development of comparative studies experienced a deep attention to the "metalegal formants" of constitutional law. In each system can be traced a set of non-juridical rules that are expression of political balances and represents the regulatory basis of the relationship between authority and people. From this point of view some years ago an Italian Author introduced the concept of «institutionalized political formula» («formula politica istituzionalizzata»), which expresses somehow the "way of thinking of the political elite" 12 .

Far to be a secondary aspect, this metalegal formant explain better than constitutional norms the fundamental characters of a national system. For example, sharing an idea of people's rights, State competence and limits of law has been the most important component of the enduring United States Constitution - while amending its text is formally simpler than other constitutions due to the absence of previsions asking for parliamentary "special majorities"13.

The metalegal formants explain some of the most questioned aspects of constitutional law. As it is - for example - how a set of norms can survive to political changes, industrial revolutions, growing complexity of social framework or, on the contrary, why the norms and their interpretation are subject of frequent and important changes.

It is not just the legal doctrine that can explain the development of a «judicial constitutionalism» in Western countries while the majority of Latin American nations has begun democratic constituent processes by means of elected assemblies ${ }^{14}$.

The promotion of some specific juridical institutions instead of others always testifies a political choice, even when the last-one is not expressed. In order to clarify how this 
works in the contemporary constitutionalism, it is useful to recall some important consideration of few years ago on the new role of Judiciary in globalization times.

The Judiciary in the contemporary law has gained a central position - or better, a «functional advantage» ${ }^{15}$ - because its typical characteristic fit the new reality of globalization on tree points. First, as a «polycentric institution», the Judiciary share with globalization the devolution of decisions-making activities: so, it guarantee a "diversification" of legal answers on the basis of the contexts. Second, the practice of jurisdiction has its main characteristic in the ability to connect private interests - that are the "impulse" of case-law and public policies - produced through the decision-making process.

Third, the jurisprudence is an increasing law-making process: courts are currently adopting a "problem-solving approach" which seems to refuse legal certainty and reinterpreting the political project of the constitution to make it fitting better present issues. While legal doctrine is progressively leaving a "positivist idea" of law, the high courts' judges act like "glocal bodies" and take inspiration by new ideas of constitutionalism, which has chosen rights - rather than democracy - as the source of legitimacy of public powers.

This trend fosters the «inner-systematic» function of rights: «the fact that the pluralistic design of contemporary constitutions gives emphasis to powerful judicial actors, usually producing and applying normative principles (rights) at a high level of international uniformity, replicates the original adaptive functions of constitutionalism» ${ }^{16}$.

The shift of Judiciary from constituted to constituent power ${ }^{17}$ is the most visible effect of globalization on the legal-formants and has opened a new challenge to the future of the democratic component of constitutionalism.

\section{ONE MORE EXAMPLE: TRACING THE MIGRATION OF CONSTITUTIONAL IDEAS. WESTERN HEGEMONY OR LEGAL PLURALISM?}

By the end of last century, comparative studies highlighted a significant increase in the reception cases of Western legal models by the remaining areas of the world. As long as globalization produced growing state's economies, the traditional institutes of liberalism first and foremost: property, contact autonomy, due process of law, anti-corruption policies were perceived as necessary conditions for a social equity and sustainable development ${ }^{18}$. Since the beginning of financial crisis the rational authority of this postulate is at stake, but 
not its effectiveness, as the developing countries' economic reliance on the lending policies of international organization is not decreased.

Consequently, among developing countries the majority of the imitations of Western normative solutions have been grounded on the conditionality ${ }^{19}$ imposed by the developed nations - on the commercial treaties - and by the international organizations - on the cooperation and development programs - rather than on the «prestige» of those models. While the "ethical dynamism of constitutions" is currently the main focus of Western doctrine and it has opened a transnational debate on the limits of judicial review, some interdisciplinary studies have highlighted the role of international investments on exporting Western ideas about private autonomy and State's power limits ${ }^{20}$.

Even if this feature of international organization is already known by international law doctrine, it never faces openly the State sovereignty as nowadays ${ }^{21}$. Actually, the increasing removal of obstacles to the full development of economic liberties beyond States boundaries - considered necessary for better working conditions ${ }^{22}$ - associate the statutory objectives of some of the most important institutions born in the early postwar: the International Bank for Reconstruction and Development (IBRD), the International Monetary Fund (IMF), the General Agreement on Trade and Services (GATT) and, last, the European Economic Community (EEC).

However, in the aftermath of Soviet disaggregation, there was an increase of developing countries adhesions to the IMF cooperation programs, of which the Western states are the main donors and promoters. The primary objective pursued by global institutions in this historical context is the adjustment of the East Europe and Asiatic economies which have quit the state-planning experience.

Thus, the adaptation of the national "legal infrastructure" to the mechanisms of world competition did not starts "free" or "spontaneous", nor affected the only commercial law. Since the beginning of the new millennium the States accession to the main organizations of international commerce and finance is subject to the acceptance of specific standards of human rights protection ${ }^{23}$.

This implies two very important consequences. First, the trade organizations can express their rating both on the level of economic liberty and the efficiency of national legal systems. Second, the States that aim to enter the system of international relations ruled by 
World Trade Organization and International Monetary Fund shall reform their normative and institutional framework in order to match the legal models recommended by the latter. Reflecting on this process, legal science has introduced the notion of «political conditionality» to indicate the set of principles and norms - derived from customary international law (jus cogens) and the main international bodies' soft law - which shape the legal category of «human rights», «democracy» and «good governance» ${ }^{24}$.

It can be traced back to these assumptions the distinction between «developed» and «developing nations» based on the presence or not of a fully evolved legal infrastructure able to efficiently regulate private trade ${ }^{25}$. This division plays a particularly important role in terms of migration of legal models. Attempts to transplant have a greater "legitimacy" when affecting the countries with a low level of development, but are generally not considered appropriate when the country "receiver" has an evolved legal system.

It is appropriate to notice that - despite their "economic vocation" - World Bank and International Monetary Fund are currently leading projects with direct effects on constitutional assets of developing countries. Thus, for example, the "strengthening" of private autonomy - even through the regulation of contractual legal relationships involving rights constitutionally established or, more generally, matters of public law - is presented as one of the most effective solution to the problems of government's corruption in developing countries $^{26}$.

The «New Directions on Justice Reform» is the World Bank document that summarizes best the "modus operandi" of international organizations. In this publication, the Legal Vice Presidency explains in detail why the judicial system of a State carries out functions critical to economic growth, highlighting three different profiles.

First, the proper functioning of justice is considered necessary to prevent crimes and mitigate the level of conflict and violence in society, identified as the main barriers to a sustainable development. Second, the democratization of the judiciary is necessary to fight against corruption, theft of public property by the ruling elites in developing countries and, more generally, in the prosecution of crimes committed in the management of the economy by the public authorities of the State.

Finally, the judicial system is recognized as an essential function of "driving" the economy, to the extent that it ensures the growth of the private sector in accordance with the framework traced by the political bodies of the country and the international bodies of the 
various business sectors.

Therefore the Legal Vice Presidency believes that the predictability of the legal effects of contracts, the presence of legal protection of property rights and a system for resolving legal disputes are «key determinants of economic development» ${ }^{27}$. In the last perspective, the «New Directions» claim a «problem-solving approach» in international cooperation ${ }^{28}$. Taking inspiration of previous experience, where attempts to transplant Western legal models have remained unfinished for the resistance of the institutional culture of the receiving countries, the Legal Vice Presidency believes that the problem is not "how" reform the judiciary, but when "when" and "why" the justice system, with its inefficiencies, undermines economic development ${ }^{29}$.

In that sense, a "virtuous transplant" is detected in the establishment of the «Arbitration Council (AC) in the United Kingdom of Cambodia, a quasi-judicial body through which the World Bank and the International Labour Organization have attempted to resolve the violent trend assumed by the union conflicts in the textile production sites. The arbitration procedure - which concerns only collective disputes - is voluntary and assumes the dual purpose of addressing the social dialectic in the legal path and, consequently, raise the productivity of the clothing industry.

The first objective is pursued with the reform of the Labor Code, which has given reception ILO's standards of workers protection. The second, through the establishment of a preliminary procedure of conciliation, which, if unsuccessful, in 15 days must be followed by the decision of a panel appointed by the parties. According to the Legal Vice Presidency, the speed and informality of the process - which anyway claims to ensure compliance with the substantive and procedural law ${ }^{30}$ - are the elements of the success of the Arbitration Council, as testified by increase of the complaints filed.

However, it is rather uncertain that - over a period of time so limited - the arbitration procedure is able to issue a decision that reflects a fair balancing of the interests of the parties, nor in compliance with the legislative framework. It is not disputed that the brevity of this term contrasts strongly with the formulations that give full investigative powers to the arbitrators about the workplace conditions or that require them to examine all the documents brought by the counterparties in support of their demands ${ }^{31}$.

Furthermore, it is necessary to note the contradictory nature of the rules of the 
arbitration procedure that, on the one hand, require the panel to decide the case in accordance with the provisions of the law ${ }^{32}$, on the other hand, ask the arbitrators for deciding only on the matter indicated by the non-conciliation report ${ }^{33}$.

This ideal of labor justice has never been questioned by the promoters of the two international projects that have given financial support to the activity of AC: the Labor Dispute Resolution Project - directed by the ILO - until 2009 and the Demand for Good Governance Project - directed by the World Bank - which was completed in March 2014. In contrast, the model of the Cambodian arbitration tribunal is sponsored by the Legal Vice Presidency of the World Bank, «[as] an example of the application of an iterative, problemsolving approach to justice reform» ${ }^{34}$.

\section{FINAL CONSIDERATIONS}

The examples above underline a strong influence of new economic assets on the traditional fields of comparative constitutional law, such as balance of State powers, legal certainty and effectiveness of social rights. Further case-studies are progressively developed with a renewed attention to the causal explanations of legal phenomena. By the means of some interdisciplinary studies we can find out an emerging conflict between constitutional law and market globalization ${ }^{35}$. In particular, while economic growth opens new possibilities for the effectiveness of some fundamental rights at the same time - as the Cambodian case demonstrates - it restricts others. It can be noticed an incompatibility between the recent evolution of productive process and the precedents social assets established during the industrial economy.

A new direction on constitutional studies can be traced if we start to analyze the "legal dynamics of globalization" - such as powerful courts and spread of arbitration - as an expression of new social assets that are growing in a transnational perspective. For example, we have seen that «labor disputes» are internationally conceived as obstacles to the economic growth and how that brings national government and business companies to cooperate in order to seek their "rapid" and "cheap" resolution through arbitration.

The former "ruling classes" and their representative institutions are unable to lead the development of social-life because the survival of financial capitalism ask for a legal standardization and transnational cooperation between States and international bodies. Thus, 
if globalization had initially promoted a "flexible and negotiated law", each time pressing international agreements are strengthening the foundation of a new transnational order. Paradigmatic of the last trend are the European Stability Mechanism - which introduces new controls on public spending - the spread of the New York Convention on the Recognition and Enforcement of Foreign Arbitral Awards of 1958 - which has now reached 154 Member States and guarantees a worldwide application of the new "lex mercatoria"36.

The Karl Polanyi's idea of a «Market Society» still has a descriptive effectiveness with regard to the dynamics that are now hegemonic in the transnational sphere of legal relationships. As in the Karl Polanyi's thought, we are not just referring at the pervasive character of trade activity in the social life of industrial countries. So, the meaning of the concept is not quantitative, but it refers to the ability showed by the capitalist system to organize separate institutions by the means of which it incessantly shapes new social dynamics and assets.

The objective may be leave a legalist approach - even if enriched by further considerations of some theory of justice - and open the analysis to extra-systemic elements. This cannot happen without a deep reflection on case-study selection, methodological studies of metalegal formants and analysis of social impact of law. The idea of market society fits into this horizon of study as element of integration of the legal system, which provides identity and stability, but at the same time, determines its receptivity to new forms of institutional rationality from outside.

\section{REFERENCES}

BOGNETTI, G. Introduzione al diritto costituzionale comparato. Il metodo, Torino, 1994.

FERRARESE, M.R. Diritto al presente. Globalizzazione e tempo delle istituzioni, Bologna, 2002.

FERRARI, G.F. Le libertà. Profili Comparatistici, Milano, 2011.

GUITIAN, M. Fund Conditionality Evolution of Principles and Practices, Washington: IMF Pamphlet Series, 1981. 
HIRSCH, R. On the blurred methodological matrix of comparative constitutional law, in S. CHOUDHRY (ed.), The migration of constitutional Ideas, Cambridge, 2006.

HIRSCHL, R. The new constitutionalism and the judicialization of pure politics in Fordham Law Review, 2007.

LEGRAND, P. What "Legal Transplants" in D. NELKEN and J. FEEST (eds.), Adapting Legal Cultures, Oxford, 2001.

LOMBARDI, G. Premesse al corso di diritto pubblico comparato. Problemi di metodo, Milano, 1986.

MATTEI, U.; NADER, L. Plunder. When the Rule of Law is Illegal, New York, 2008.

Mc CONNAUGAY, P.J. The Scope of Autonomy in International Contracts and Its Relation to Economic Regulation and Development, in Columbia Journal of Transnational Law, Vol. 39, 2000.

MIAILLE ,M. Introduzione ad uno studio critico del diritto, Roma, 1979.

SACCO R., Introduzione al diritto comparato, Torino, 1990.

THORNHILL, C. Contemporary constitutionalism and the dialectic of constituent powers, in Global Constitutionalism, Issue 3, 2012.

UVIN, P.; BIAGIOTTI, I. Global Governance and the "New" Political Conditionality, in Global Governance, 2 (1996).

VEZZANI, S. Gli accordi delle Organizzazioni del Gruppo Banca Mondiale.

Von BENDA-BECKMANN, F.; Von BENDA-BECKMANN K.; GRIFFITHS, A. The Power of Law in a Transnational World. Anthropological Enquiries, New York-Oxford, 2009.

WORLD BANK, Justice Reform Projects in Latin America: Lessons Learned (1995-2010), Working Paper No. 70755, 2011.

WORLD BANK, New Directions on Justice Reform - A companion piece to the updated strategy and implementation plan on strengthening governance tackling corruption, Working Paper no. 70640, 2012. 
1 R. SACCO, Introduzione al diritto comparato, Torino, 1990, p.161.

2 R. HIRSCH, On the blurred methodological matrix of comparative constitutional law, in S. CHOUDHRY (ed.), The migration of constitutional Ideas, Cambridge, 2006, p. 39.

3 Ivi, p. 43 and 46.

$4 \quad$ Ivi, p. 46.

5 Ivi, p. 43.

6 P.LEGRAND, What “Legal Transplants" in D. NELKEN and J. FEEST (eds.), Adapting Legal Cultures, Oxford, 2001, p.55.

${ }^{7}$ R. HIRSCHL, The new constitutionalism and the judicialization of pure politics in Fordham Law Review, 2007, n. 75, p. 721-753.

8 Among them, see M. MIAILLE, Introduzione ad uno studio critico del diritto, Roma, 1979.

9 See M. MIAILLE, Introduzione ad uno studio critico del diritto, cit., p.65-66

10 Ivi, p. 167

11 For an Italian perspective on this problem, see G.F. FERRARI, Le libertà, Milano, 2011, p.324-325.

12 See G. LOMBARDI, Premesse al corso di diritto pubblico comparato. Problemi di metodo, Milano, 1986, p.70.

13 See G. BOGNETTI, Introduzione al diritto costituzionale comparato. Il metodo, Torino, 1994, p.155.

14 See C. THORNHILL, Contemporary constitutionalism and the dialectic of constituent powers, in Global Constitutionalism, Issue 3, 2012, p. 392-3.

15 See M.R. FERRARESE, Diritto al presente. Globalizzazione e tempo delle istituzioni, Bologna, 2002 , p. 81.

16 See C. THORNHILL, Contemporary constitutionalism and the dialectic of constituent powers, cit., p. 393.

17 Ivi, p.375.

18 This are the theoretical premises of Word Bank's cooperation projects with developing countries since the World Development Report 1999.

19 Since 1952, the principle of conditionality has been implicitly introduced by the International Monetary Fund (IMF) triennial grant policies to force the beneficiary states to adopt a specific balance approach, characterized by a restrictive orientation on public spending. The practice of financial conditionality has known a growing legitimation and diffusion among the lending policies due above all to its convergence function between the objectives of contracting parties: the beneficiary interest in obtaining the lending is bound to the implementation of the politics that the borrower considers more appropriate to ensure production growth and, with this, the successful conclusion of the relation with the restitution of the amount agreed. On this argument, see M.GUITIAN, Fund Conditionality Evolution of Principles and Practices, Washington: IMF Pamphlet Series, 1981, pp.10-14. After its extension to bilateral and multilateral archetype of non-lending agreements, the practice of conditionality was formalized by art. 60 of Vienna Convention on the Law of Treaties of 1969, which states that «the violation of a provision essential to the accomplishment or object or purpose of the treaty» represents a «material breach» that authorizes the parties to «terminate the treaty or suspending its operation in whole or in part». Not every infringement authorized the suspension of relationships, but only those that interest the essential clauses identified by the parties or identifiable through the interpretation of the provisions.

20 U. MATTEI, L. NADER, Plunder. When the Rule of Law is Illegal, New York, 2008, p.59. The Authors point out the different ways of legal models migration: apart from military domination and the «prestige» of a normative institute, can be traced another way, the «conditional imposition». This expression means that «the acceptance of a system of rules is not totally free. The interested countries are persuaded to adopt the legal structures which meet Western standards if they do not want to be excluded from the international market».

21 See, S. VEZZANI, Gli accordi delle Organizzazioni del Gruppo Banca Mondiale, Torino: Giappichelli, 2011.

22 One of the main objectives of the IBRD's Articles of Agreement (1944) is «to promote the long-range balanced growth of international trade and the maintenance of equilibrium in balances of payments by encouraging international investment for the development of the productive resources of members, thereby assisting in raising productivity, the standard of living and conditions of labor in their territories» (Article 1).

23 M.R. FERRARESE, Il diritto al presente. Globalizzazione e tempo delle istituzioni, Bologna, 2002, p. 116

24 P. UVIN; I. BIAGIOTTI, Global Governance and the "New" Political Conditionality, in Global Governance, 2 (1996), p. 377: "Yet political conditionality may also be more broadly defined as a set of 
specific state behaviors - respecting human rights, organizing multiparty elections, working in a good governance mode, and cutting military spending - that are internationally upheld as conducive to development and whose realization is promoted, inter alia, through that leverage instrument. The specific state behaviors that are promoted may be said to constitute a regime: sets of internationally dominant principles and norms around which expectations converge and that define acceptable state behavior for both recipient and donor countries»

25 P.J. Mc CONNAUGAY, The Scope of Autonomy in International Contracts and Its Relation to Economic Regulation and Development, in Columbia Journal of Transnational Law, Vol. 39, december 2000, p. 601. It is interesting to read the Author's word: «This Article distinguishes "developed" from "developing" nations in a purely functional way. Developed nations are those nations that enjoy fully developed legal infrastructures and the ability to effectively regulate commercial activity-principally the major industrialized trading nations of the West, perhaps along with the few most advanced industrialized nations of Asia. Developing nations are those nations whose judicial and commercial regulatory institutions lack the capacity to perform their prescribed or intended functions effectively, whether because the institutions do not exist, because they are under-developed, because they are under-funded, or because of some other disabling attribute, such as corruption»

26 P.J. Mc CONNAUGAY, The Scope of Autonomy in International Contracts and Its Relation to Economic Regulation and Development, cit., p. 603

27 See, New Directions on Justice Reform - A companion piece to the updated strategy and implementation plan on strengthening governance tackling corruption, Working Paper no. 70640, 2012, p.3-4, available on line: http://documents.worldbank.org/curated/en/2012/05/16706679/world-bank-new-directions-justicereform-companion-piece-updated-strategy-implementation-plan-strengthening-governance-tacklingcorruption.

28 Justice Reform Projects in Latin America: Lessons Learned (1995-2010), Working Paper No. 70755, 2011, p. 7.

29 New Directions on Justice Reform, cit., p. 9

30 Art. 34, Prakas 99 of 21 April 2004, issued by the Cambodian Ministry of Labor: «In matters referred to the arbitration panel, the panel shall have the power and authority to fully remedy any violation of provisions provided in the Labour Law, implementing regulations under the Labour Law, collective bargaining agreements or other obligations arising from the professional relationship between employer and employee. Within the limitations of the Labour Law and this Prakas, it has the power and authority to provide any civil remedy or relief which it deems just and fair [...]».

31 Article 312, par. 3 e 4, of Labor Code: «The Council of Arbitration has a broad power to investigate the economic situation of the enterprises and the social situation of the workers involved in the dispute. The Council has the power to make all inquiries into the enterprises or the professional organizations, as well as the power to require the parties to present any document or economic, accounting, statistical, financial, or administrative information that would be useful in accomplishing its mission. The Council may also solicit the assistance of experts».

32 Art. 312, Cambodian Labour Code: «The Council of Arbitration legally decides on disputes concerning the interpretation and enforcement of laws or regulations or of a collective agreement. The Council's decisions are in equity for all other disputes».

33 Article 312, par. 1, of Labor Code: «The Council of Arbitration has no duty to examine issues other than those specified in the non-conciliation report or matters, which arise from events subsequent to the report, that are the direct consequence of the current dispute».

34 See, New Directions on Justice Reform, cit., p. 9.

35 See, for example, F. Von BENDA-BECKMANN, K. Von BENDA-BECKMANN, A. GRIFFITHS, The Power of Law in a Transnational World. Anthropological Enquiries, New York-Oxford, 2009.

36 For a comparative perspective of the new characteristics of arbitration and its perspective of development, see J. PAULSSON, The Idea of Arbitration, Oxford, 2013. 
Are Brazilian Courts Democratic Institutions? A Hermeneutic Analysis of Legitimacy

Artigo recebido em 08 de setembro de 2016 e aceito em 13 de junho de 2017 